J. Swartz MD FRCPC, M. Cumming RN BSC, D. Biehl MD FRCPC

\section{The effect of ketamine anaesthesia on the acidotic fetal lamb}

The degree of fetal acidosis and the effects of anaesthetic agents on the stressed fetus are difficult to quantitate clinically. ${ }^{1}$ However, the presence of fetal distress may necessitate expeditious delivery, often by Caesarean section under general anaesthesia. The best combination of anaesthetic agents remains to be determined.

Previous work from our laboratory suggests that in the severely asphyxiated fetus blood pressure and cerebral blood flow may be better preserved using ketamine rather than thiopentone for induction of anaesthesia. ${ }^{2}$ The advantages of ketamine in this setting are its rapid onset of action and its potent analgesic and amnesic properties. Ketamine allows the administration of 100 per cent oxygen to the parturient and provides haemodynamic stability.

In previous studies we have used a model of fetal asphyxia involving partial occlusion of the umbilical cord to document the haemodynamic and acid-base changes that occur with time. ${ }^{3,4}$ The purpose of this present study was to examine the haemodynamic effects of ketamine: oxygen anaesthesia on the asphyxiated fetal lamb in comparison with a non-anaesthetized control group.

\section{Methods}

Consent for this protocol was obtained from the Animal Care Committee of the University of Manitoba. Fifteen pregnant ewes of 125-135 days gestation (term 150 days) were surgically prepared as previously described. ${ }^{5}$ Briefly, under general anaesthesia polyvinyl catheters were placed in the maternal femoral artery and vein. Via a hysterotomy incision, polyvinyl catheters were placed in the fetal femoral artery and vein and brachial artery. An occlusion loop was secured loosely around the umbilical cord and the hysterotomy incision closed. All animals were allowed to recover for $48-72$ hours following surgery. No animal was included in the study unless fetal arterial $\mathrm{PO}_{2}$ was greater than 15 tor and $\mathrm{pH}$ was greater than 7.30. On the day of study a maternal tracheostomy was performed under halothane:oxygen mask anaesthesia. Lidocaine two per cent $5 \mathrm{cc}$ was injected into the trachea with insertion of the tracheostomy tube. Each animal was allowed to recover for a minimum of one hour breathing humidified oxygen at a rate of 15 litres per minute. The tracheostomy was done to avoid diffi- 
TABLE I Matcmal pulse rate and blood pressure in the control group (A) and the ketamine: $\mathrm{O}_{2}$ anaesthesia group (B) during control period, production of fetal acidosis and with general anuesthesia (mean \pm SEM)

\begin{tabular}{|c|c|c|c|c|c|}
\hline & \multicolumn{2}{|l|}{ Control } & \multirow{2}{*}{$\begin{array}{l}\text { Fetal acidosis } \\
(p H 7.12-7.13)\end{array}$} & \multicolumn{2}{|c|}{$\begin{array}{l}\text { Fetal acidosis plus anaes- } \\
\text { thesia (Group B) }\end{array}$} \\
\hline & $15 \min$ & $30 \min$ & & $5 \min$ & $15 \mathrm{~min}$ \\
\hline \multicolumn{6}{|c|}{ Pulse rate } \\
\hline $\begin{array}{l}\text { Group A } \\
n=7\end{array}$ & $95 \pm 7.6$ & $92 \pm 7.9$ & $92 \pm 9.0$ & $91=8.7$ & $88 \pm 9.5$ \\
\hline $\begin{array}{l}\text { Croup B } \\
n=8\end{array}$ & $100 \pm 5.7$ & $100 \pm 4.6$ & $100 \pm 5.2$ & $98 \pm 4.7$ & $100 \pm S .1$ \\
\hline \multicolumn{6}{|c|}{ Mean arterial blood pressure (MABP) } \\
\hline $\begin{array}{l}\text { Group A } \\
n=7\end{array}$ & $84 \pm 3.7$ & $82 \pm 3.4$ & $80 \pm 4.7$ & $80 \pm 5.5$ & $81 \pm 3.2$ \\
\hline $\begin{array}{l}\text { Group B } \\
\mathrm{I}=8\end{array}$ & $96 \pm 7.0$ & $96 \pm 4.4$ & $89 \pm 4.7$ & $103 \pm 5.5^{*}$ & $100 \pm 5.0^{*}$ \\
\hline
\end{tabular}

* $p<0.05$ compared 10 Group $A$ ar 5 and 15 minutes.

culties with airway instrumentation during the anaesthesia partion of the study.

During each study maternal and fetal mean arterial blood pressure (MABP) and pulse rates were recorded continuously on a Hewlett-Packard multi-channel recorder. Blood samples were obtained from the matemal femoral artery and the fetal brachial artery for $\mathrm{pH}$ and blood gas analysis at 15-minute intervals or more frequently as required during asphyxia. Fetal blood losses were replaced with normal saline.

Each study began with a control period of 30 minutes to ensure stability of the preparation. The ewe breathed humidified oxygen at a flow rate of 15 litres per minute via the tracheostomy and received a volume load of $500 \mathrm{ml}$ of normal saline followed by an infusion of $150 \mathrm{ml} \cdot \mathrm{hr}^{-1}$. At the conclusion of the control period the umbilical cord occlusion loop was gradually inflated until fetal $\mathrm{pH}$ was 7.12-7.15. This usually required 90 minutes.

When this $\mathrm{pH}$ range was obtained the first injection of radioactive chromium, cerium, or strontium labelled microspheres (diameter 10 micron, $3 \mathrm{M}$ Company, Minneapolis) was made. This technique has previously been described. ${ }^{5}$

Following the first microsphere injection the animals were randomly assigned to one of two groups. Group A $(n=7)$ received no anaesthesia and served as the control group. Ewes in Group A continued to breathe humidified oxygen at $15 \mathrm{~L} \cdot \mathrm{min}^{-1}$ for 15 minutes. Repeat microsphere injections were made at 5 and 15 minutes. Group $\mathrm{B}(\mathrm{n}=8)$ received ketamine $3 \mathrm{mg} \cdot \mathrm{kg}^{-1}$ intravenously via the matemal femoral vein catheter for induction of anaesthesia. A second dose of ketamine $1 \mathrm{mg} \cdot \mathrm{kg}^{-1}$ was administered at ten minutes postinduction to maintain anaesthesia for the duration of the study period. All animals received 100 per cent oxygen and ventilation was controlled to maintain a nomal $\mathrm{PCO}_{2}$. In both groups the occlusion loop remained inflated for the duration of the study. The second and third microsphere injections were made at 5 and 15 minutes following induction of anaesthesia.

After the third microsphere injection all animals were killed with an injection of thiopentone, followed by $\mathrm{KCl}$. The fetuses were removed, weighed, and dissected. The fetal brain, heart, and kidneys were separately weighed, ground, and ashed. Microsphere counts were performed on these samples and the counts wcrc compared with the reference blood samples to calculate organ blood flow. ${ }^{6}$ Blood flow to the right and left kidneys were calculated separately to serve as a marker for even distribution of microspheres to all organs. Discrepancy between right and left kidney flow suggests uneven mixing of the microspheres.

\section{Statistical analysis}

Maternal and fetal MABP, pulse rate, blood gases, $\mathrm{pH}$ and organ blood flows were subjected to analysis of variance for repeated measures to detect significant changes within groups. Intergroup comparisons were performed by the unpaired Student's $t$ test. A p value $<0.05$ was considered statistically significant.

\section{Results}

\section{Maternal changes (Table I)}

There were no significant changes in the maternal pulse rate, $\mathrm{PCO}_{2}$, or base excess ( $\mathrm{BE}$ ) in either group during the study. Matemal arterial $\mathrm{PO}_{2}$ in both groups was $195-230 \mathrm{mmHg}$ during the control period and during the time when fetal acidosis was being produced. In Group $B$, with anaesthesia and controlled ventilation maternal $\mathrm{PO}_{2}$ rose significantly to $306 \pm 37.3 \mathrm{mmHg}$ and remained above $300 \mathrm{mmHg}$ for the duration of the ketamine anaes- 
TABLE II Fetal pulse rate, blood pressure, and blood gases in the control group (A) and the ketamine: $\mathrm{O}_{2}$ anaesthesia group (B) during control period, production of acidosis and with general anaesthesia (mean $\pm S E M$ )

\begin{tabular}{|c|c|c|c|c|c|}
\hline & \multicolumn{2}{|l|}{ Control } & \multirow{2}{*}{$\begin{array}{l}\text { Fetal acidosis } \\
\text { (pH } 7.12-7.13)\end{array}$} & \multicolumn{2}{|c|}{ Acidosis plus anoesthesia (Group B) } \\
\hline & $15 \min$ & $30 \min$ & & $5 \mathrm{~min}$ & $15 \min$ \\
\hline \multicolumn{6}{|l|}{ Pulse rate } \\
\hline Group A & $146 \pm 4.9$ & $148 \pm 6.3$ & $123 \pm 13.11$ & $113 \pm 9.2$ & $10 S \pm 16.3 \dagger$ \\
\hline Group B & $146 \pm 5.0$ & $153 \pm 2.5$ & $133 \pm 11.84$ & $171 \pm 15.07 t$ & $166 \pm 14.7 \uparrow \ddagger$ \\
\hline \multicolumn{6}{|c|}{ Mean arterial blood pressure (MABP) } \\
\hline Group A & $54 \pm 3.9$ & $55 \pm 2.5$ & $72 \pm 5.8 \dagger$ & $73 \pm 5.0^{\circ}$ & $66 \pm 8.5 \dagger$ \\
\hline Group B & $56 \pm 3.1$ & $58 \pm 3.0$ & $71 \pm 6.0 \dagger$ & $61 \pm 5.5$ & $56 \pm 5.4$ \\
\hline \multicolumn{6}{|l|}{$p H$} \\
\hline Group A & $7.34 \pm 0.02$ & $7.36 \pm 0.03$ & $7.12 \pm 0.01 \div$ & $7.09 \pm 0.02 \dagger$ & $7.02=0.02 \ddagger$ \\
\hline Group B & $7.41 \pm 0.01$ & $7.42 \pm 1.01$ & $7.13 \pm 1.02 \div$ & $7.08 \pm 0.02 \dagger$ & $7.07 \pm 0.02 \uparrow$ \\
\hline \multicolumn{6}{|c|}{$\mathrm{PCO}_{2}(\mathrm{mmHg})$} \\
\hline Group A & $40 \pm 1.8$ & $40 \pm 1.8$ & $57 \pm 2.7 \dagger$ & $58 \pm 1.9 \uparrow$ & $70 \pm 7.1$ 林 \\
\hline Group B & $37 \pm 1.3$ & $34 \pm 0.8$ & $48 \pm 14.7 \dagger$ & $53 \pm 4.1 \dagger$ & $58 \pm 3.6 \dagger$ \\
\hline \multicolumn{6}{|c|}{$\mathrm{PO}_{2}(\mathrm{mmHg})$} \\
\hline Group A & $25 \pm 2.4$ & $23 \pm 2.4$ & $20 \pm 2.2$ & $20 \pm 2.6$ & $17 \pm 1.3$ \\
\hline Group B & $21 \pm 1.1$ & $19 \pm 1.2$ & $19 \pm 1.8$ & $22 \pm 2.5$ & $20 \pm 3.2$ \\
\hline
\end{tabular}

${ }^{*} p<0.05$ compared to asphyxia values in the same group

$\dagger_{p}<0.05$ compared to control yalues in the same group.

$\ddagger \mathrm{p}<0.05$ compared to Group $\mathrm{A}$ at 5 and 15 minutes.

thesia. Maternal pH decreased significantly in Group B from $7.52 \pm 0.03$ during control to $7.47 \pm 0.03$ prior to anaesthesia. After 15 minutes of anaesthesia the materna] $\mathrm{pH}$ was $7.44 \pm 0.04$. However the $\mathrm{pH}$ in Group B was not significantly different from the $\mathrm{pH}$ in Group $\mathrm{A}$ at any time during the study.

Production of fetal asphyxia (Table II)

Inflation of the umbilical occlusion loop over a 60-90 minute period resulted in a statistically significant decrease in fetal $\mathrm{pH}$ to a range of 7.12-7.13. Fetal MABP increased from a range of 54-58 to $71-72 \mathrm{mmHg}$ and pulse rate decreased from $146-153$ to $123-133$ beats $\mathrm{min}^{-1}$. These measurements were significantly different from control in both groups and persisted for the duration of the study in the nonanaesthetized Group $\mathrm{A}$. There were no changes in fetal $\mathrm{PO}_{2}$ measured from the brachial artery in either group during the production of acidosis or during anaesthesia. Fetal $\mathrm{PCO}_{2}$ rose significantly from $37-40 \mathrm{mmHg}$ prior to cord occlusion to $48-57 \mathrm{mmHg}$ with acidosis. Base excess decreased significantly from -2.4 to -0.4 to -10 to -13 in the two groups.

Fetal effects of ketcmine anaesthesia (Table II)

Group A: This group received no anaesthesia. There were no further changes in MABP, pulse rate, blood gases or $\mathrm{pH}$,
Group B: Induction of anaesthesia with ketamine $3 \mathrm{mg} \cdot \mathrm{kg}^{-1}$ in the ewe abolished the fetal hypertensive response to acidosis with a significant fall in MABP from $71 \pm 6.0 \mathrm{mmHg}$ to $61 \pm 5.5 \mathrm{mmHg}$. Ketamine anaesthesia also resulted in fetal tachycardia with an increase in pulse rate from $133 \pm 12$ to $171 \pm 15$ beats $\cdot \mathrm{min}^{-1}$ within five minutes. This persisted for the duration of the study. This increase was significant when compared to values just prior to induction of anaesthesia and to values at 5 and 15 minutes in Group $A$. There were no significant changes in blood gases or $\mathrm{pH}$.

FETAL BLOOD FLOWS (Table III)

Total cerebral blood flow was in the range of 2.87-3.87 $\mathrm{ml} \cdot \mathrm{g}^{-1} \cdot \mathrm{min}^{-1}$ in both groups $\mathrm{A}$ and $\mathrm{B}$ following production of fetal acidosis. There were no significant differenees between the two groups at the 5 and 15 minute measurements. There were also no significant differences between the groups in myocardial or renal blood flow. Right and left renal blood flow were similar indicating equal distribution of microspheres.

\section{Discussion}

Perinatal asphyxia may result in permanent neurological sequelae in the newborn. ${ }^{7,8}$ The mechanism of injury to the central nervous system appcars to depend primarily on abnormal cerebral perfusion. Acidosis and asphyxia 
TABLE ]II Organ blood flows (m] $\left.\cdot \mathrm{g}^{-1} \cdot \mathrm{min}^{-1}\right)$ just prior to, and after 5 and 15 minutes of anaesthesia* (meun $\left.=S E M\right)$

\begin{tabular}{|c|c|c|c|c|c|c|}
\hline & & Acidosis & & 5 Minules & & 15 Minuies \\
\hline \multicolumn{7}{|l|}{ Brain } \\
\hline $\begin{array}{l}\text { Group A } \\
n=7\end{array}$ & & $3.87 \pm 0.36$ & & $3.69 \pm 0.45$ & & $3.12 \pm 0.75$ \\
\hline $\begin{array}{l}\text { Group B } \\
n=8\end{array}$ & & $2.87 \pm 0.68$ & & $2.30 \pm 0.68$ & & $3.03 \pm 0.90$ \\
\hline \multicolumn{7}{|l|}{ Heart } \\
\hline Group A & & $2.47 \pm 0.61$ & & $1.70 \pm 0.31$ & & $2.34 \pm 0.40$ \\
\hline Group B & & $1.39 \pm 10.23$ & & $1.51 \pm 0.35$ & & $1.90 \pm 0.56$ \\
\hline Renal & $R$ & $L$ & $R$ & $L$ & $R$ & $L$ \\
\hline Group A & $0.57 \pm 0.10$ & $0.67 \pm 0.09$ & $0.59=0.08$ & $0.61 \pm 0.09$ & $0.51 \pm 0.13$ & $0.56 \pm 0.15$ \\
\hline Group B & $0.59 \pm 0.14$ & $0.69 \pm 0.18$ & $0.62=0.09$ & $0.69 \pm 0.24$ & $0.73 \pm 0.22$ & $0.85 \pm 0.30$ \\
\hline
\end{tabular}

*Anaesthesia in Group B only.

result in a pressure passive cerebral vasculature with loss of auto-regulation of cerebral perfusion in response to changes in blood pressure. ${ }^{3.9 .10}$ The asphyxiated fetus or newborn is then exposed to two potential hazards: hypotension with resultant cerebral ischaemia or hypertension with increased risk of intracerebral haemorrhage.

Umbilical cord compression produces both respiratory and metabolic acidosis in the fetal lamb. Cardiac output is severely reduced due to decreased venous retum. Gas exchange is impaired due to reduced flow to the placenta. Acidosis shifts the oxyhaemoglobin dissociation curve to the right with desaturation of haemoglobin and reduction of oxygen content. ${ }^{2}$ In response to acidosis and hypovolaemia, fetal blood pressure increases in an attempt to maintain perfusion and oxygen supply to vital organs such as the brain and heart. This increase in MABP is due to peripheral vasoconstriction mediated via the sympathetic nervous system. "The decrease in pulse rate implies an intact baroreceptor response to hypertension. As previously reported, the consistently increased cerebral blood flow seen in this sheep model represents attempts by the fetus to maintain oxygen supply to the brain in the face of hypovolacmia and reduced oxygen content. $^{3}$

Induction of anaesthesia with ketamine in Group B abolished the hypertension and bradycardia produced by cord occlusion. The increase in heart rate was unable to compensate for the loss of the vasoconstrictor response, however, and fetal MABP dropped significantly. These results are similar to our previous findings using thiopentone for anaesthetic induction and halothane:oxygen or halothane:nitrous oxide:oxygen for maintenance of anaesthesia. ${ }^{5}$ However, in those experiments, fetal MABP fell to values significantly below the MABP in the control asphyxiated but unanaesthetized fetuses. In the present study, ketamine anaesthesia resulted in a 20 per cent fall in fetal MABP. The MABP range in both groups was wide, however, so no significant difference between Groups A and B was observed. All fetuses survived the 15-minute post-asphyxia period under anaesthesia and despite the fall in fetal MABP cerebral and myocardial perfusion were maintained.

Other authors have shown that ketamine does not reduce uterinc blood flow at a dose of $5 \mathrm{mg} \cdot \mathrm{kg}^{-1}$ in the pregnant ewe. ${ }^{12}$ These investigators demonstrated that uterine blood flow increased concomitantly with increased cardiac output and maternal blood pressure following ketamine administration. Uterine tone has been shown to increase in the pregnant ewe following low dose ketamine $\left(0.7 \mathrm{mg} \cdot \mathrm{kg}^{-1}\right)$ but in the same study, uterine blood flow was maintained secondary to increased cardiac output. ${ }^{13}$ Low-dose ketamine $\left(0.6-1 \mathrm{mg} \cdot \mathrm{kg}^{-1}\right)$ administered to pregnant women at term does not increase resting uterine tone. ${ }^{14-16}$ Ketamine administered to the term parturient in doses greater than $1.0 \mathrm{mg} \cdot \mathrm{kg}^{-1}$ may increase the intensity of uterine contractions. ${ }^{16}$ Although it is difficult to extrapolate from animal studies to the clinical situation, one may speculate that uterine and feto-placental perfusion are well maintained following ketamine anaesthesia in the parturient with an adequate intravascular blood volume.

When fetal asphyxia is severe the time from diagnosis to delivery is an important factor in determining survival. Fetal compensatory mechanisms ultimately fail at some critical point with resultant demise. In this study we observed that ketamine anaesthesia abolishes the compensatory mechanisms of hypertension and bradycardia seen with partial cord occlusion. Nevertheless, with severe acidosis ( $\mathrm{pH}<7.15$ ), ketamine anaesthesia does not produce significant deterioration in fetal blood gases, $\mathrm{pH}$, or in cerebral and myocardial blood flow.

Ketamine has been recommended as an alternative 
anaesthetic induction agent to thiopentone for elective Caesarean section. ${ }^{17-19}$ The clinical situation of severe fetal distress may necessitate a general anaesthetic and there may be insufficient time for a regional technique. Our current findings corroborate the results of previous studies and suggest that ketamine is a safe anaesthetic agent in acute fetal distress.

\section{References}

1 Miller FC. Prediction of acid-base values from intrapartum fctal hcart ratc data and their correlation with scalp and funic values. Clin Perinatol 1982; 9: 352-62.

2 Pickering BG, Palahniuk RJ, Coie J, Wade JG, Push $M G$. Cerebral vascular responses to ketamine and thiopentone during foetal acidosis. Can Anaesth Soc J 1982; 29: 463-7.

3 Johnson GN, Palahniuk RI, Tweed WA, Jones MV. Wade JG. Regional cerebral blond fow changes during severe fetal asphyxia produced by slow partial unbilical cord compression. Am J Obstet Gynecol 1979; 135: 48-52.

4 Yarnell $R$, Bieht $D R$, Pucci $W$. Redistribution of cardiac output in foetal sheep in response to umbilical cord compression. SOAP Abstract Booklet. Vancouver, B.C. May, 1983.

5 Swartz J, Cumming $M$, Pucci $W$, Biehl DR. The effects of general anaesthesia on the asphyxiated foetal lamb in utero. Can Anaesth Soc J 1985; 32: 577-82.

6 Rudolph AM, Heymarn MA. The circulation of the fetus in utero: methods for studying distribution of blood flow, cardiac output, and organ blood flow. Circ Res 1967; 21: 163-7|.

7 Weindling AM, Wilkinson AR, Cook J et al. Perinatal events which precede periventricular haemorrhage and leukomalacia in the newborn. Br J Obstet Gynecol 1985; 92 : 1218-23

8 Shenan AT, Milligan JE, Hoskins EM. Perinatal factors associated with death or handicap in very preterm infants. Am J Obstet Gynecol 1985; 151: 231-8.

9 Lou HC, Lassen NA, Friis-Hasen B. Impaired autoregulation of cerebral blood blow in the distressed newborn infant. J Ped 1979; 94: 118.

10 Lou HC, Lassen NA, Tweed WA et al. Pressure passive cerebral blood flow and breakdown of the hlond brain barrier in experimental foetal asphyxia. Acta Paed Scand 1979; 68: 57.

11 Hutson MI, Mueller-Heuback E. Diagnosis and management of intrapartum reflex fetal heart rate changes. Clin Perinatol 1982; 9: 325-38.

12 Levinson $G$, Shnider SM, Gildea JE, DeLurimer AA. Maternal and foetal cardiovascular and acid-base changes during ketamine anaesthesia in pregnant ewes. $\mathrm{B}_{\mathrm{J}} \mathrm{J}$ Anaesth $1973 ; 45 ; 1111-5$.
13 Craft JB, Coaldrake LA, Yonekura ML et al. Ketamine, catecholamines, and uterine tone in pregnant ewes. Am J Obstet Gynecol 1983; 146; 429-34.

14 Oats $J N$, Waldron BA. Effects of ketamine on the pregnant uterus. Br J Anaesth 1979; 5I: 1163-5.

15 Galloon $S$. Ketamine for obstetric delivery. Anesthesiology 1976; 6: 522-4.

16 Marx GF, Hwang HS, Chandra $P$. Postpartum uterine pressures with different doses of ketamine. Anesthesiology $1979 ; 2: 163-6$

17 Peliz $B$, Sinciair DM. Induction agents for caesarean see* tion: a comparison of thiopentone and kctamine. Anaesthesia $1973 ; 28: 37-42$.

18 Dich-Nielson J, Holasek $K$. Ketamine as induction agent for caesarean section. Acta Anaesthesiol Scand 1982; 26: $139-42$.

19 Schultetus RR, Paulus DA, Spohr GL. Haemodynamic effects of ketamine and thiopentone during anaestheric in duction for Caesarean section. Can Anaesth Soc J 1985; 32: 592-6.

\section{Résumé}

La présente étude fut faite sur des brebis pleines afun d'examiner les effets de l'anesthésie à la kétamine-oxygène sur le fortus de la brebis rendu acidotique par occlusion partielle du cordon ombilical.

Quinze brebis pleines étaient instrumemées sous anesthésie générale afin de permettre la mesure continuelle de la pression artérielle moyenne muternelle et forale ainsi que la mesure du pouls et l'étude de la gazométrie. Un tourniquet pouvant permettre l'acclusion fut installé awour du cordon ombilical.

Après une période de recouvrement de 48 heures une trachéostomie fut faite pour chaque brebis. Après une période de contrôte l'occlusion du cordon ombilical fut accomplie lente. ment jusqu' à la diminution du $\mathrm{pH}$ fatal à 7.12-7.15. Après l'occlusion les animaux furen divisés en deux groupes $A$ et $B$. Le groupe $A n^{\prime}$ a reçu aucune anesthésie. Dans le groupe $B$, les brebis ont reçu de la këtamine $3 \mathrm{mg} \cdot \mathrm{kg}^{-1}$ par voie intraveimeuse et leur ventilation fut contrôlée avec une $\mathrm{F}_{1} \mathrm{O}_{2}$ de 1.0 . Dix minutes plus tard de la kétamine $1 \mathrm{mg} \cdot \mathrm{kg}^{-1}$ fut donnée. Dans les deux groupes des microsphères radioactifs furent injectés dans le fotus à 0,5 , et 15 minutes.

L'anesthésie à la kétamine chez les brebis pleines a aboli l'hypertension et la bradycardie produite par l'occlusion partielle du cordon ombilical chez les fortus. Tous les fotus ont survécu les 15 minutes de l'anesthésie à la kétamine et il n'y avait aucun changement significatif des gaz sanguins artériels ou du pH. Les fots sanguins déterminés par la méthodes des microsphères pour le cerveau, cour et reins ne furent pas significativement altérés par la kétamine. On conche que l'anesthésie à la kétamine-oxygène n'amène pas l'avantage de détérioration chez le fortus acidotique des brebis. 